\title{
Media and Political Parties Two Sides of Coin in Democracy
}

\author{
Ghulam Safdar $^{1, *}$, Ghulam Shabir ${ }^{2}$, Abdul Wajid Khan ${ }^{1}$ \\ ${ }^{1}$ Department of Media Studies, The Islamia University of Bahawalpur, Pakistan \\ ${ }^{2}$ Department of Communication Studies, Bahauddin Zakariya University Multan, Pakistan
}

Copyright $\bigcirc 2016$ by authors, all rights reserved. Authors agree that this article remains permanently open access under the terms of the Creative Commons Attribution License 4.0 international License.

\begin{abstract}
Democracy is government of people. In democratic states people choose their leaders to make government to lead the country and political parties connect with the people with the help of mass media. The present study conducted in southern Punjab Pakistan to know about the relationship of media and political parties in the term of strengthening democracy. The study conducted under the light of "Agenda Setting Theory". Survey methodology was used to collect the data from the target public. The results showed that media and political parties have strong relation to promote democracy. Moreover, media and political parties monitor each other so that no one could cross its limit according to responsibilities.
\end{abstract}

Keywords Promoting Democracy, Media, Political Parties, Public

\section{Introduction}

Politics and democracy are two edge of river that become together. Democracy is a form of accountable governance. Transparent politics is the foundation of democracy. In Pakistan, democracy has lot of problems about citizen's power and rights, low quality of democracy, lack of governance and leadership. In Pakistan, it considered that political leadership often fails to fulfill promises, people hops and equal accountability for all classes of society. It is the key point of good democracy that there should be good governance, justice, accountability, liberty, allegiance, legitimacy and other matters that affect the people in their daily life. According to Dahl (1976), Politics can be defined as the presence of authority and power involved polishing political process by reshaping it in different period of time. So, democratic process extends even those who do not participate in politics. In this modern mediated age, social relationship plays important role in politics. People become the part of politics intentionally or unintentionally.

Politics is such phenomenon which can be found in all groups of societies and institutions involving all human related to private or public sector. It can be seen in the activities like negotiations, cooperation and great effort to use, produce and distribute the resources. Political power can effect on the distribution and usage of resources. Politics has transformative capacity of institutions and social agencies. Only government is not involved in this process (Held, 1995).

Heywood defines politics that "it is a social activity that arises out of interaction between the people". In other way, politics is the presence of authority. Political process is decision making process about the distribution of resources (Heywood, 1994:17). He also describe that political parties contain different opinion and interests. These opinions closely linked to the conflicts that differentiate opinions and beliefs among people according to their interests. Politics involves power, leadership, influence of government, relationship with other countries and management of conflicts. Media is being used for making political process more inclusive and open and playing important role in governance and accountability.

Overall literacy rate of Pakistan is not high especially in rural areas people have no better qualification. Usually cable network is not available in rural areas and one and only PTV is seen in the rural areas. Due to lack of education, rural people have no understanding about political awareness and they see TV for entertainment. The rural places where TV is rare, they use Radio as source of entertainment and information. In rural areas, mostly people get political awareness from other people usually local political leaders. Whereas, in urban area, literacy rates are better and people have more understanding capacity of political situation. Moreover, in urban areas there is lot of sources of political awareness like radio, newspapers, cable TV network. In Pakistan more than 75 TV channels are working and near about 75 more have gained the NOC from PEMRA. Usually Urban people don't believe on rumors. They believe on facts and have power to understand the situation. Due to large amount of facilities, urban people get different news about politics and government from different 
sources like newspapers, TV and social media.

\section{Objectives of the Study}

The basic objectives of the presents study are;

- To know about the political situation in Pakistan.

- To know about the relationship of media and political parties in Pakistan.

- To know about the public perception regarding media and political parties.

- To know about the role of media in promotion of political system.

- To know about the media agenda in term of political opinion in Pakistan.

- To know about the democratic system in Pakistan.

\section{Literature Review}

Loveless (2009: 119) argue that circulation of democracy through media consists on the idea that cultural look should be inserted in the broadcasting data. In this way of transmission, normative politics and social values are broadcasted from one country to the target country. In this way targeted country public attach these values strongly.

According to the Christians et al. (2009) Media has played the important role in building such ideas in which society could be operate. For this purpose, effected perception and attitudes are necessary. Media is a mirror that reflects the public issues. Media caused by the awareness about state polities and important events in the public. Media and journalism has a big role in change. Media's role is facilitative by 'dazzling the political conditions where the people are located and provide a plate form to promote dialogue among their audiences through communication. On the other hand strong democracy rely on educated and inform society and that information plays important role in society.

Katrin Voltmer \& G. Rownsley (2009) describe the relation of media and democracy as, Media has been recognized as the potential and influential in the democratization. As the current global wave of democracy take place in the mediated environment. In modern democracies the media often seem to lack the qualities. But the world qualifies the media for playing key role in promoting inclusive politics and accountability. Media can play watch dog role and can criticize easily on the political system as they are more close to the political power holders. True political reporting is necessary that provide balanced gatekeeping. Commercial pressures on news coverage encourage and fulfill the expense and sustain attention on complex issues, international affairs and policy agenda. Global media can also contribute in democratization by directing foreign political authorities and audiences towards problems in a particular country.

Marjut Johansson (2008) Political system is not complete without casting the vote by its citizens. Actually, voting is a secret act of democracy and every person has right to vote any political party according to his/her interests and mental satisfaction. In every societies, there are some basic standards for each citizen empowered to elect representatives by the casting his/her vote. But is that enough for the promotion, development and completion of democratic system?

A Theorist Rosa Maria Alfaro (2006) Asserts that "Today media shape crucial source of education and legitimization of democratic power. Political leaders legitimize themselves or join with dissidents through newspapers, radio, magazines and television. Themes of political parties are highlighted through the daily programs of mass media and particularly via news. The National and International agenda is exposed daily from mass media. The feelings and concept of Nation and of the world are also disseminated from the media. It is possibility that most troubling about the democracy is that it links the media to the formation of audiences, assumptions about political practice suggesting the kind of democracy".

McQuail (2005) says all democratic characteristics including national and international depends on media. There are some issues that are discussed without interfering media. Media concern with all essential issues which are relates to the society and those who concern the sharing and use of power. The supervision of troubles and the process of combination, change communications messages delivered by the public are in the form of information, stories, belief or diversion. Media consists on such institutions and technologies that perform various functions. Media is apparatuses that mediate between two or more parties. Usually we use the term mass media which is organized way to communication openly and at a long distance to large number of receivers within short period of time.

Randall (1998) said media is considered more helpful for democracy at a specific political condition while political parties try to cross the limits that identified by the democracy. So media identified the process of democracy. Moreover fulfill the public expectations from news and change of political condition. According to Randall, "At the start, media role will more limited but to the extant media offers alternative account of social and political reality and even they draw people into a sense of shared public space. In this way, media is seen as helping to improve the democratization process".

According to the Wheeler (1997) and Grossman (1996) "information and communication" are measured very important tools in any democracy in which without information and communication, the structure of supremacy would not stay alive. Its realities that for successful democracy, continual discussion, debate, analysis and study is necessary, which is called communications-intensive mode of governance. Different perspectives about reliable information and different views about different issues, public give their own views on different issues that provide help in preparing political participation. Media is such vehicle from where masses get and spread political information. Mass media is powerful tool which provide 
information between political elites and the electorate. Its reality that media makes this possible for widely spread citizens to receive, disseminate information which is available to them through the mass media.

Mancini (1993) argued that "The relationship between political parties and politicians on one hand and the media and journalism on the other operate with the common strategy of fulfill the interests and the relationship of these parties lies between trust and suspicion".

Garramone and Atkin (1986) conduct a study on the basis of "Two kinds of political knowledge and two forms of political behavior and effect of TV, Radio, Newspaper and Magazine were compared". In this study, the political interests in media of different age groups were examined. Result of the study was that electronic media news was strongly knowledge about politics as compare to print media. The researcher also concluded that electronic media news were improved forecaster about any political issue instead of old knowledge. On the other hand print media forecast equally these two types of knowledge. Further researcher concluded that news telecast or broadcast on electronic media has greater exposure and closely related to the interpersonal communication.

\section{Theoretical Framework}

The present study conducted under the light of "agenda setting theory" that highlight the importance of media related to the public opinion and force the audience what to be read and what the important issues are. Pakistan is multicultural and Multilanguage country. It is reality that majority of the people relay on media and political parties use media to communicate their message to the target audiences.

\section{Methodology}

Methodology is the procedure that is used to conduct the research. The methodology of the present study is survey. Survey is a method to collect the data in the form of interview or take the answers of question written in the questionnaire. The researcher designs a comprehensive questionnaire to collect the data from the target public. The data is collected from southern Punjab, Pakistan.

\section{Research Questions}

1) Do for the promotion of democracy which is importance, Media or Political Leaders?

2) Do media cross its limit related to its responsibilities?

3) Do political parties cross their limit to pressurize media to get advantage?

4) Do political parties choose media to convince people to cast the vote?

\section{Hypothesis}

H 1: It is more likely that clashes exist among the media and government.

H 2: It is more likely that media and political parties both playing their role for the promotion of democracy.

\section{Interpretation of Findings}

This study presented the data about media, political awareness, making political opinion, political parties, and presentation in making strong democracy, auditing political parties, guiding government in developing country.

A total of 450 respondents from Southern Punjab filled the questionnaire, 228 were males and 222 were females filled the questionnaire. As shown in the table 1, majority of respondents were 18 to 28 years old (68.9 percent), 29 to 38 (21.7 percent), 39 to 48 (7.1 percent) and above 48 are (2.2 percent) respectively of the total population.

Table 1 shows that majority of the respondents are graduates (29.6 percent), intermediate (24.9 percent), masters (24.7 percent), metric (17.8 percent), below metric (2.0 percent) and above masters (1.1 percent) respectively.

Table 1. Demographic Characteristics of the Respondents

\begin{tabular}{|c|c|c|c|c|}
\hline $\begin{array}{l}\text { Sr. } \\
\text { No. }\end{array}$ & $\begin{array}{c}\text { Demographic } \\
\text { Characteristics }\end{array}$ & $\begin{array}{l}\text { Description of } \\
\text { Characteristics }\end{array}$ & $\mathrm{F}$ & $\%$ \\
\hline \multirow{3}{*}{1} & \multirow{2}{*}{ Gender } & Male & 228 & 50.7 \\
\hline & & Female & 222 & 49.3 \\
\hline & Total & & 450 & 100 \\
\hline \multirow{5}{*}{2} & \multirow{4}{*}{ Age } & $18-28$ & 310 & 68.9 \\
\hline & & $29-38$ & 98 & 21.7 \\
\hline & & $39-48$ & 32 & 7.1 \\
\hline & & Above 48 & 10 & 2.2 \\
\hline & Total & & 450 & 100 \\
\hline \multirow{7}{*}{3} & \multirow{6}{*}{ Education } & Below Metric & 9 & 2.0 \\
\hline & & Metric & 80 & 17.8 \\
\hline & & Intermediate & 112 & 24.9 \\
\hline & & Graduation & 133 & 29.6 \\
\hline & & Master & 111 & 24.7 \\
\hline & & Above & 5 & 1.1 \\
\hline & Total & & 450 & 100 \\
\hline
\end{tabular}






Note: The above frequency distribution graph shows the answer of statement "Media and Political Leaders both plays important role in promoting democracy?". According to the collected data, 26.4\% respondents strongly agreed and said that yes media and Political Leaders both plays important role for the promotion of democracy, $38.0 \%$ respondents agreed, $14.2 \%$ respondents said that have no idea about this statement, whereas $16.2 \%$ disagreed and $5.1 \%$ respondents strong disagreed with the statement.

Figure 1. Demographic Media and Political Leaders role in democracy

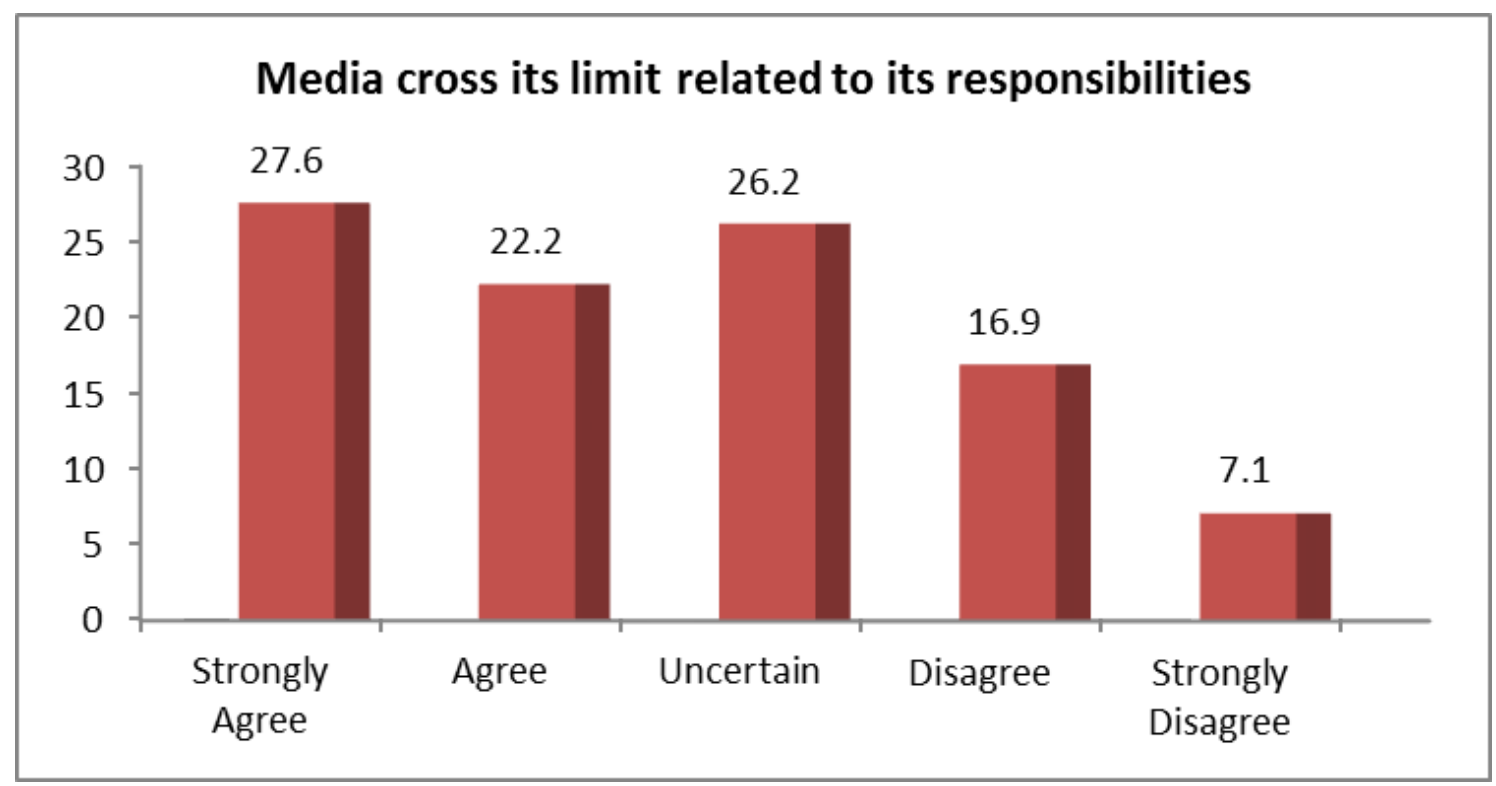

Note: The above frequency distribution graph shows the answer of statement "Media cross its limit related to its responsibilities?" According to the results, $27.6 \%$ respondents strongly agreed with the statement and said that media cross its limit related to its responsibilities, $22.2 \%$ respondents agreed with the statement, $26.2 \%$ respondents said that they have no idea about the answer of the respective statement, $16.9 \%$ respondents disagreed whereas $7.1 \%$ respondents strongly disagreed with the statement and said that no media not cross its limit.

Figure 2. Demographic media cross its limit related to its responsibilities. 


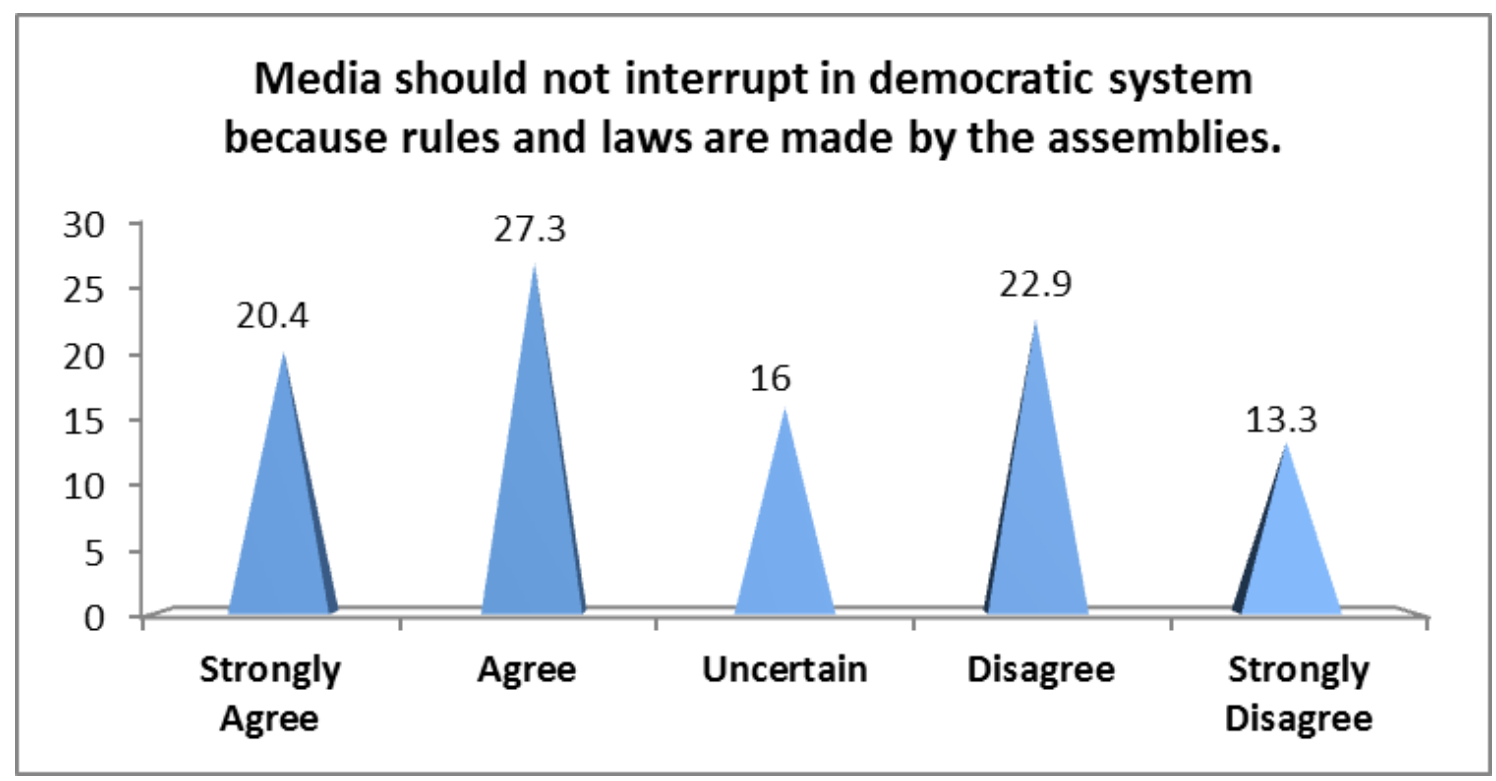

Note: The above frequency distribution graph shows the answer of statement "Media should not interrupt in democratic system because rules and laws are made by the assemblies". According to the collected data, $20.4 \%$ respondents strongly agreed that assemblies are working well so there is no need to interrupt media, $27.3 \%$ agreed with the statement, $16.0 \%$ respondents said that they are not sure about the answer of the respective statement, whereas $22.9 \%$ disagreed and $13.3 \%$ respondents strongly disagreed and said that media should interrupt in democratic system because in assemblies ruling parties try to make such rule and laws that may against the solidarity of the country.

Figure 3. Media interruption and democratic system

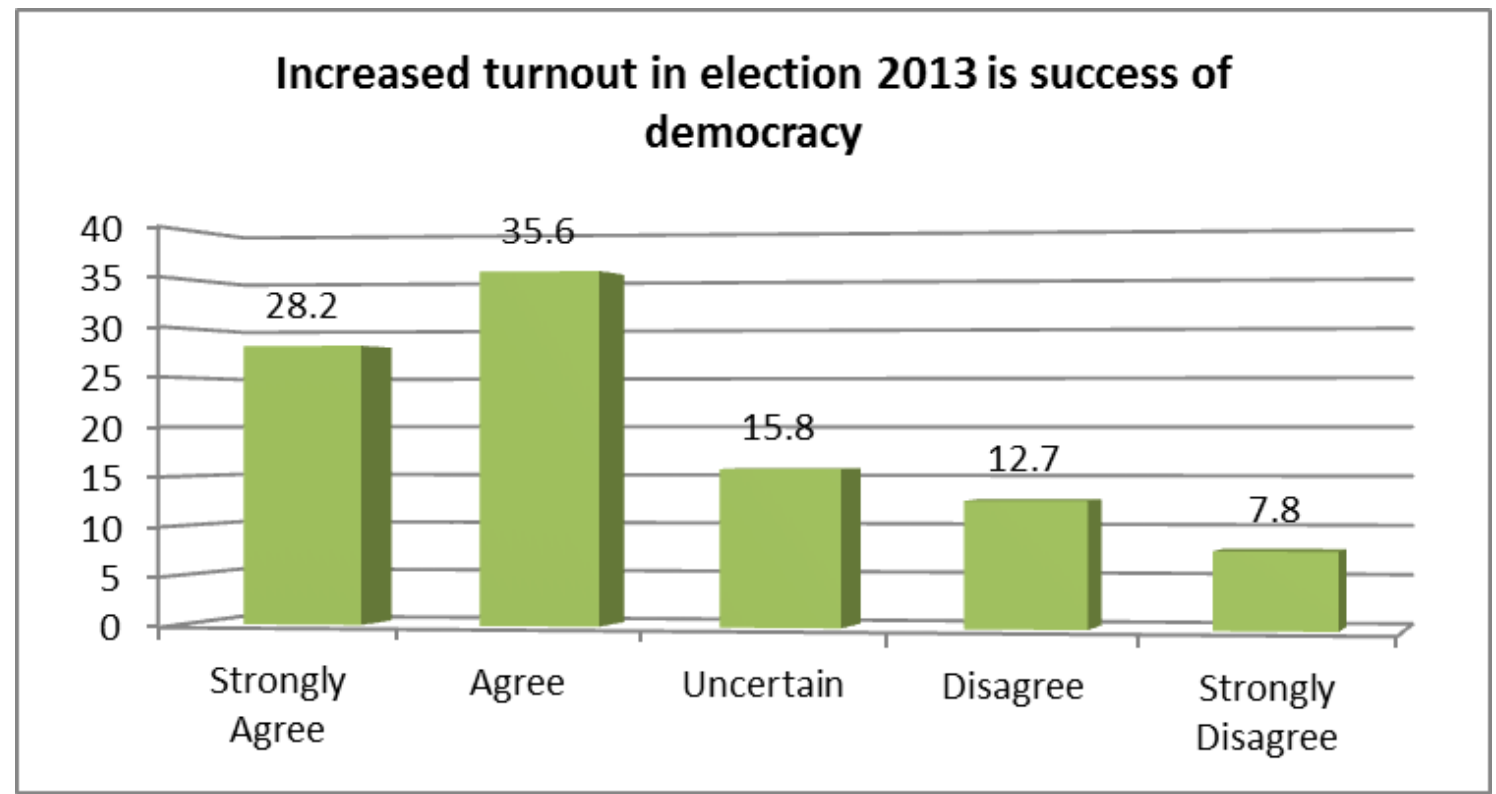

Note: The above frequency distribution graph shows the answer of statement "Increased Turn-out in Election 2013 is success of democracy". According to the results $28.2 \%$ respondents strongly agreed that increased turn-out in general election 2013 is success of democracy, $35.6 \%$ agreed with the statement, whereas $15.8 \%$ respondents said that they have no idea about this statement, moreover $12.7 \%$ disagreed and $7.8 \%$ respondents strongly disagreed and said that increasing turn-out in general elections 2013 is not success of democracy.

Figure 4. Demographic increasing turn-out is success of democracy. 


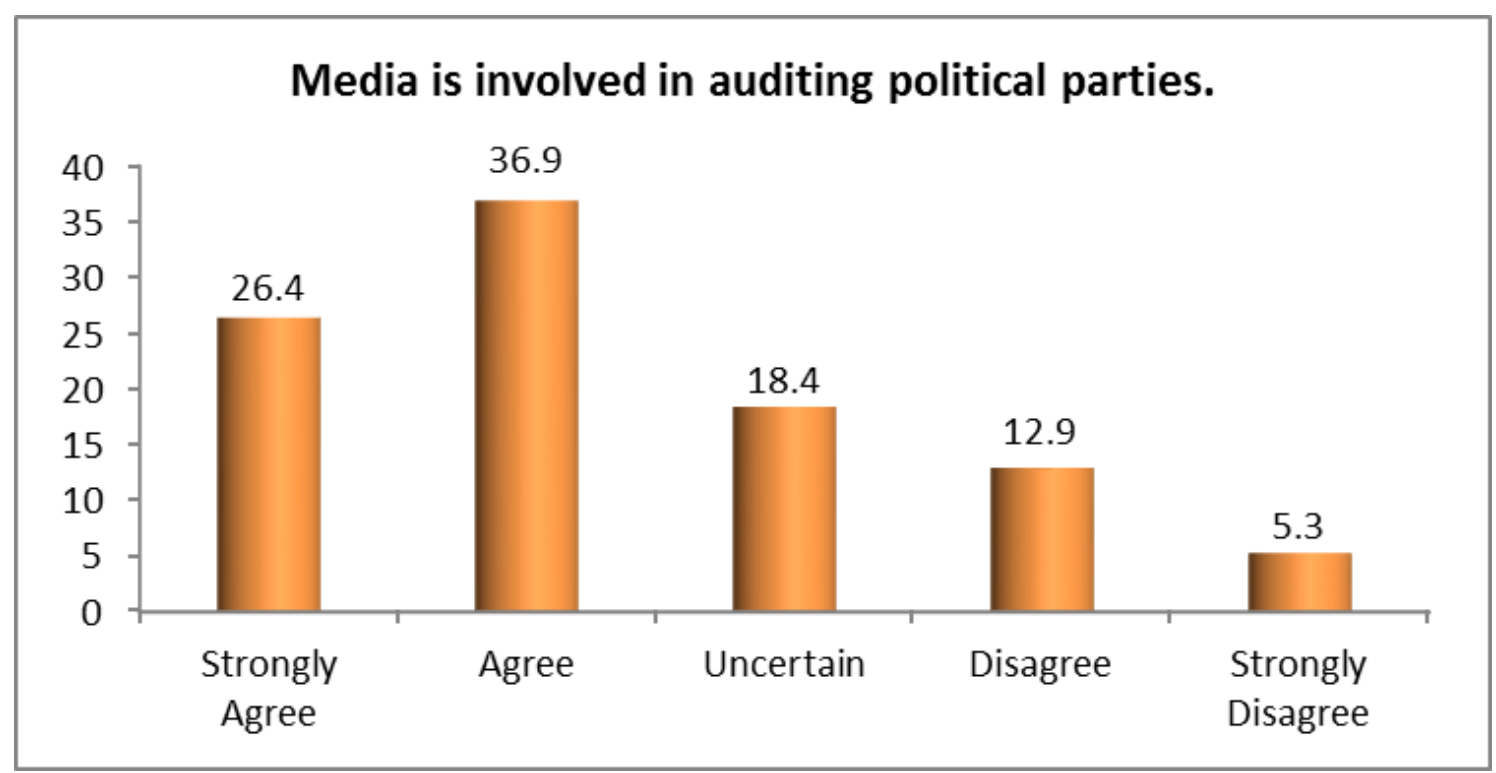

Note: The above frequency distribution graph shows the answer of statement "Media is involved in auditing political parties" According to the results, $26.4 \%$ respondents strongly agreed with the statement that media is involved in auditing political parties, $36.9 \%$ respondents agreed with the statement, $18.4 \%$ respondents said that they have no idea about the answer of the given statement, $12.9 \%$ respondents disagreed and $5.3 \%$ strongly disagreed with the statement and said that media is not involves in auditing political parties.

Figure 5. Demographic media audit to political parties.

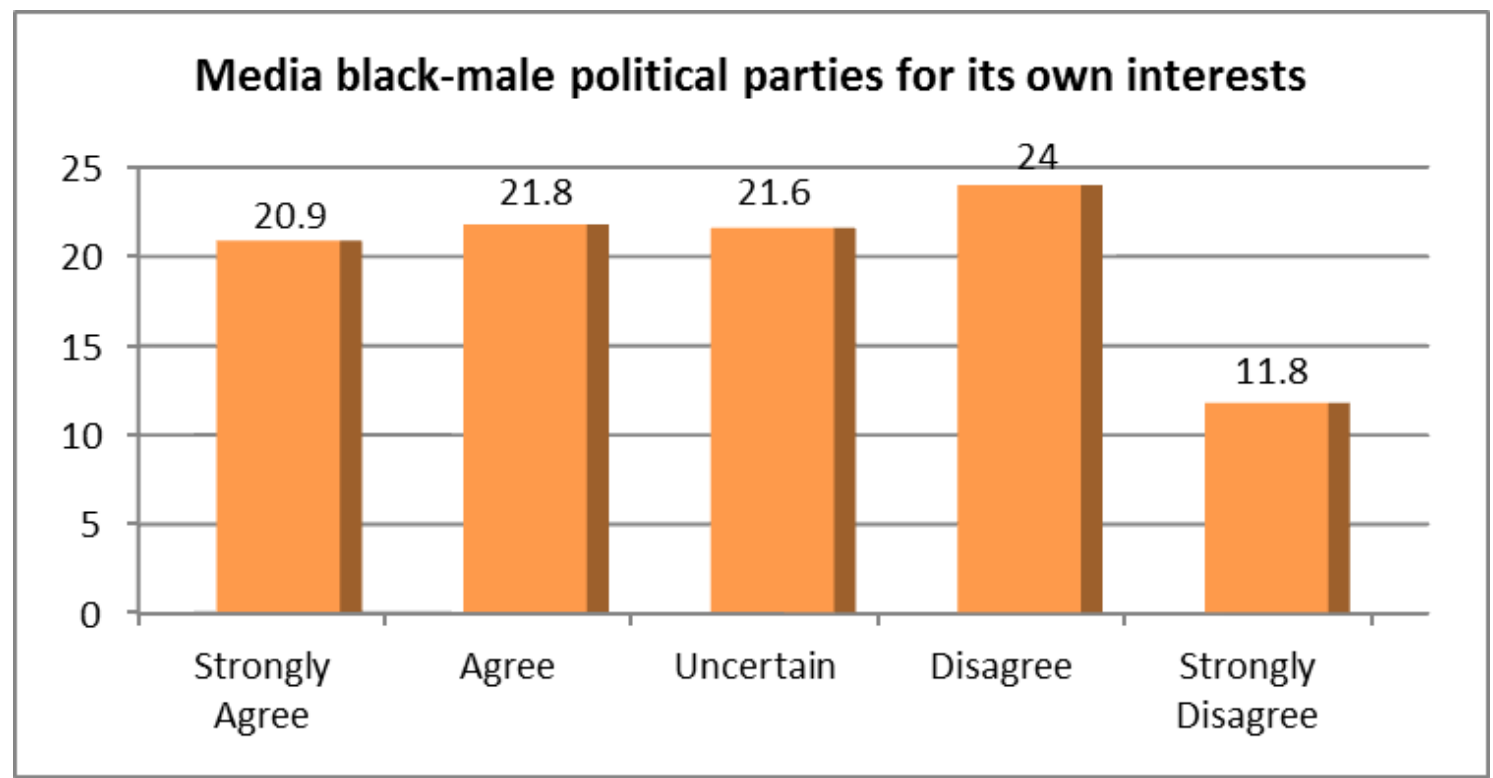

Note: The above frequency distribution graph shows the answer of statement "Media black-male political parties for its own interests". According to the results $20.9 \%$ respondents strongly agreed and said that its reality that media black-male political parties for its own interests, $21.8 \%$ respondents agreed with the statement, $21.6 \%$ respondents said that they have no idea about the answer of this statement, whereas $24.0 \%$ respondents disagreed and $11.8 \%$ respondents strongly disagreed with the statement and said that media do not black-male political parties for its own interests.

Figure 6. Demographic media black male political parties. 


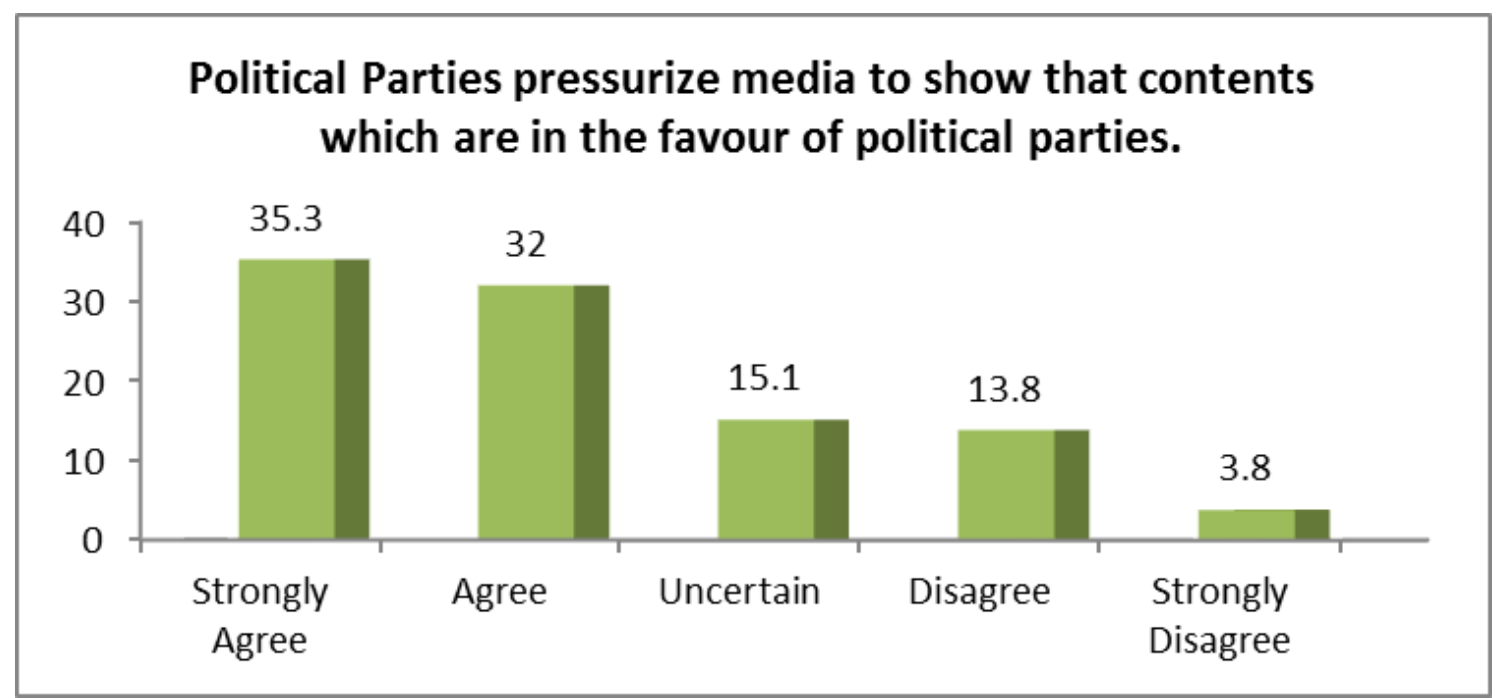

Note: The above frequency distribution graph shows the answer of statement "Political parties pressurize media to show that contents which are in the favour of political parties". According to the collected data, $35.3 \%$ respondents strongly agreed with the statement that political parties pressurize media to shows the contents which goes to their favour, $32.0 \%$ respondents agreed with the statement, $15.1 \%$ respondents said that they have no idea about the answer of the given statement, whereas $13.8 \%$ respondents disagreed and $3.8 \%$ respondents strongly disagreed with the statement and said that political parties do not pressurize media to show that contents which are in their favour.

Figure 7. Demographic pressures of political parties on media.

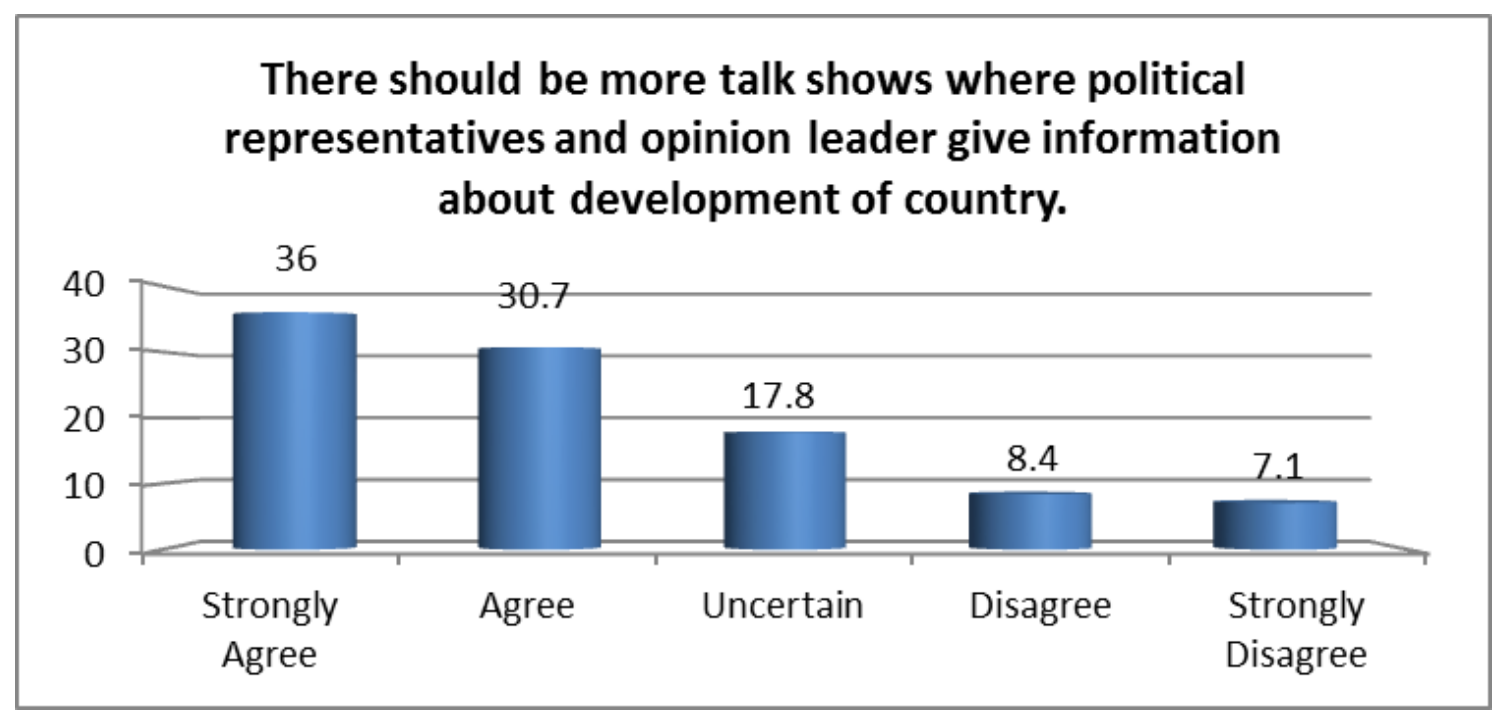

Note: The above frequency distribution graph shows the answer of statement "There should be more talk shows where political representatives and opinion leaders give information about development of country". According to the collected data, $36.0 \%$ respondents strongly agreed on the statement that there should be more talk shows, $30.7 \%$ respondents agreed on this statement, $17.8 \%$ respondents said that they have no idea about the answer of the given statement, whereas $8.4 \%$ respondents disagreed and $7.1 \%$ respondents strongly disagreed on this statement and said that there should not be more talk shows because talk shows are like puppet shows.

Figure 8. Demographic there should be more talk shows for political information. 


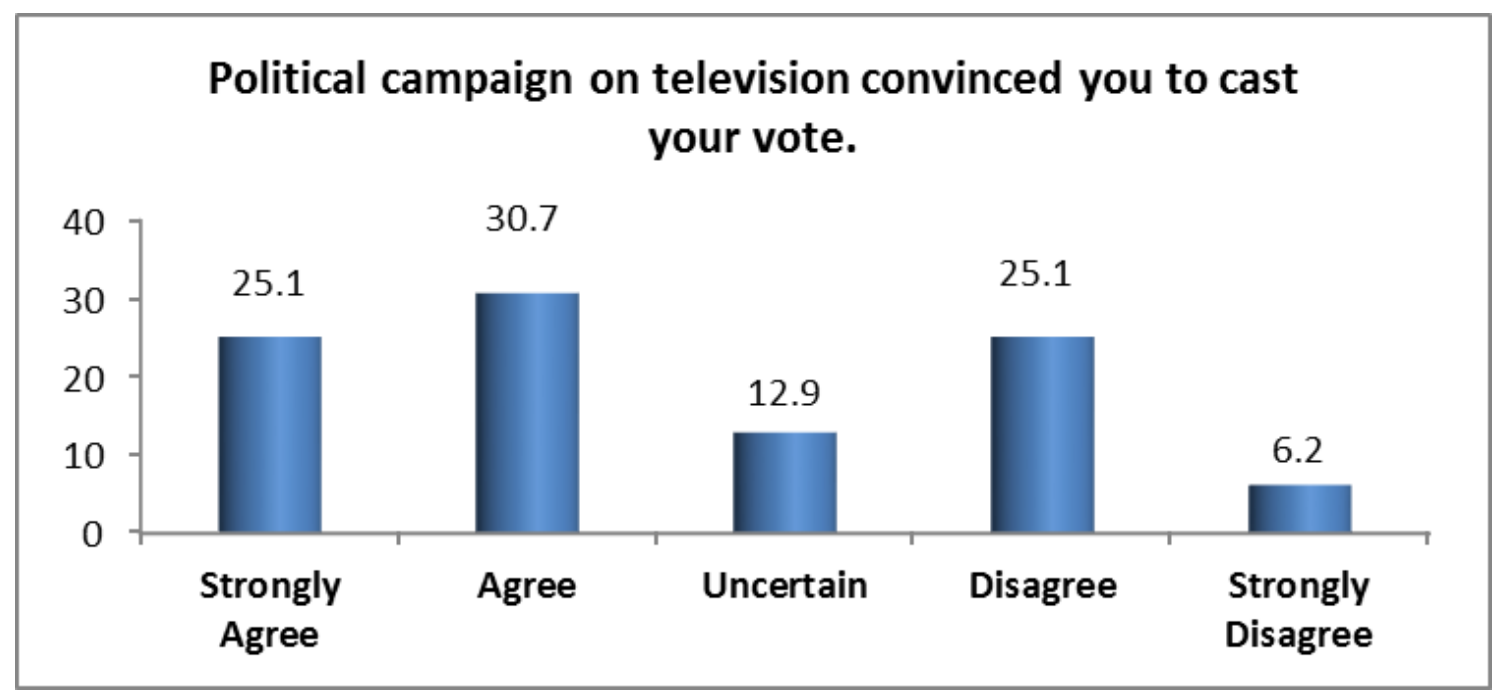

Note: The above frequency distribution graph shows the answer of statement "Political campaign on television convinced you to cast your vote". According to the collected data $25.1 \%$ respondents strongly agreed that media convinced them to cast the vote, $30.7 \%$ respondents agreed about the statement, $12.9 \%$ respondents said that they are not sure and have no opinion against the respective statement, $25.1 \%$ respondents disagreed and argue that they convinced by other sources to cast the vote and $6.2 \%$ respondents strongly disagreed on the statement and said that political campaign on television has not convince them to cast the vote.

Figure 9. Role of Political campaign on TV in convincing people to cast the vote

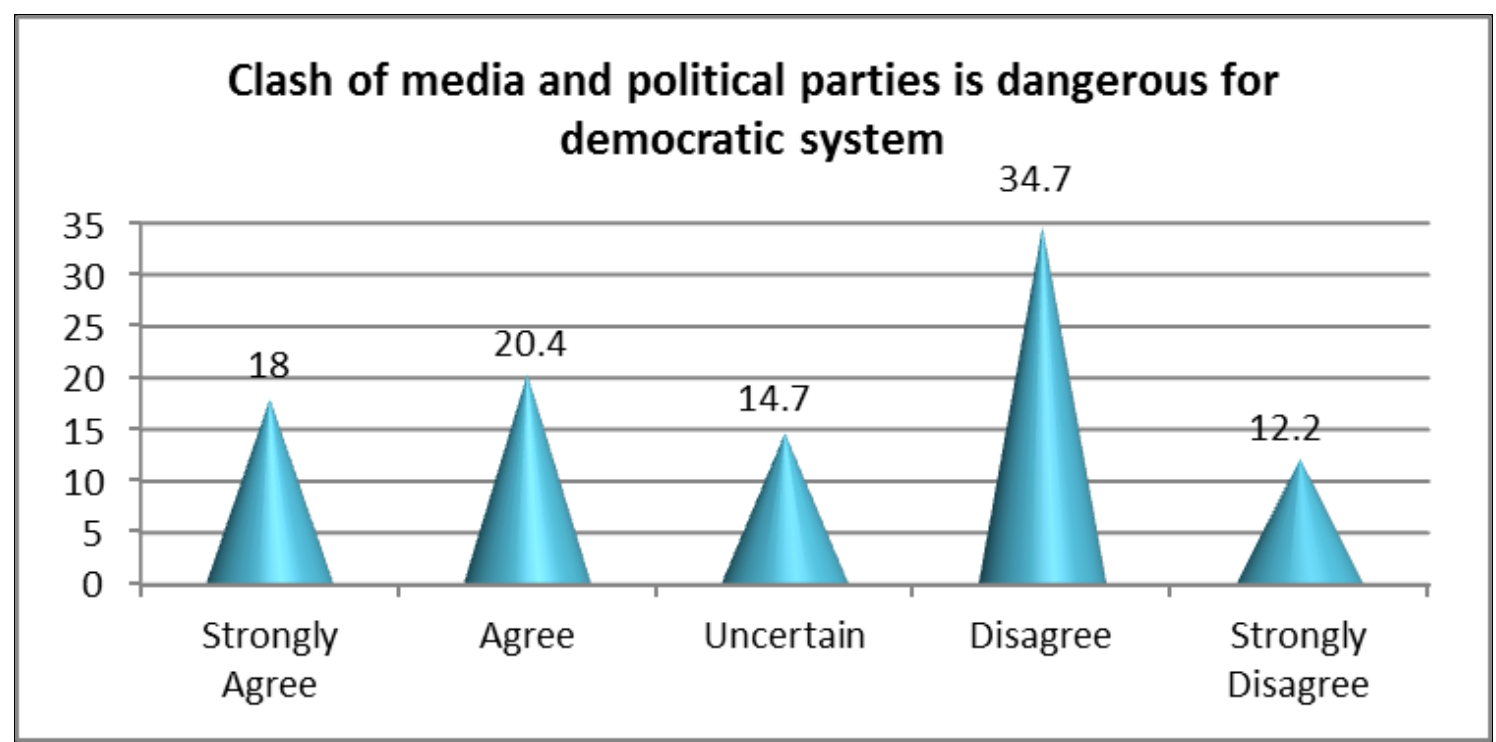

Note: The above frequency distribution graph shows the answer of statement "Clash of media and political parties is dangerous for democratic system". The results shows that, $18.0 \%$ respondents strongly agreed with the statement that clash of media and political parties are dangerous for democracy, $20.4 \%$ respondents agreed with the statement, $14.7 \%$ respondents said that they have no idea about the answer of the given statement, whereas $34.7 \%$ respondents disagreed and $12.2 \%$ respondents strongly disagreed and said that clash of media and political parties are not dangerous for democracy.

Figure 10. Clash of media and political parties is dangerous for democratic system. 


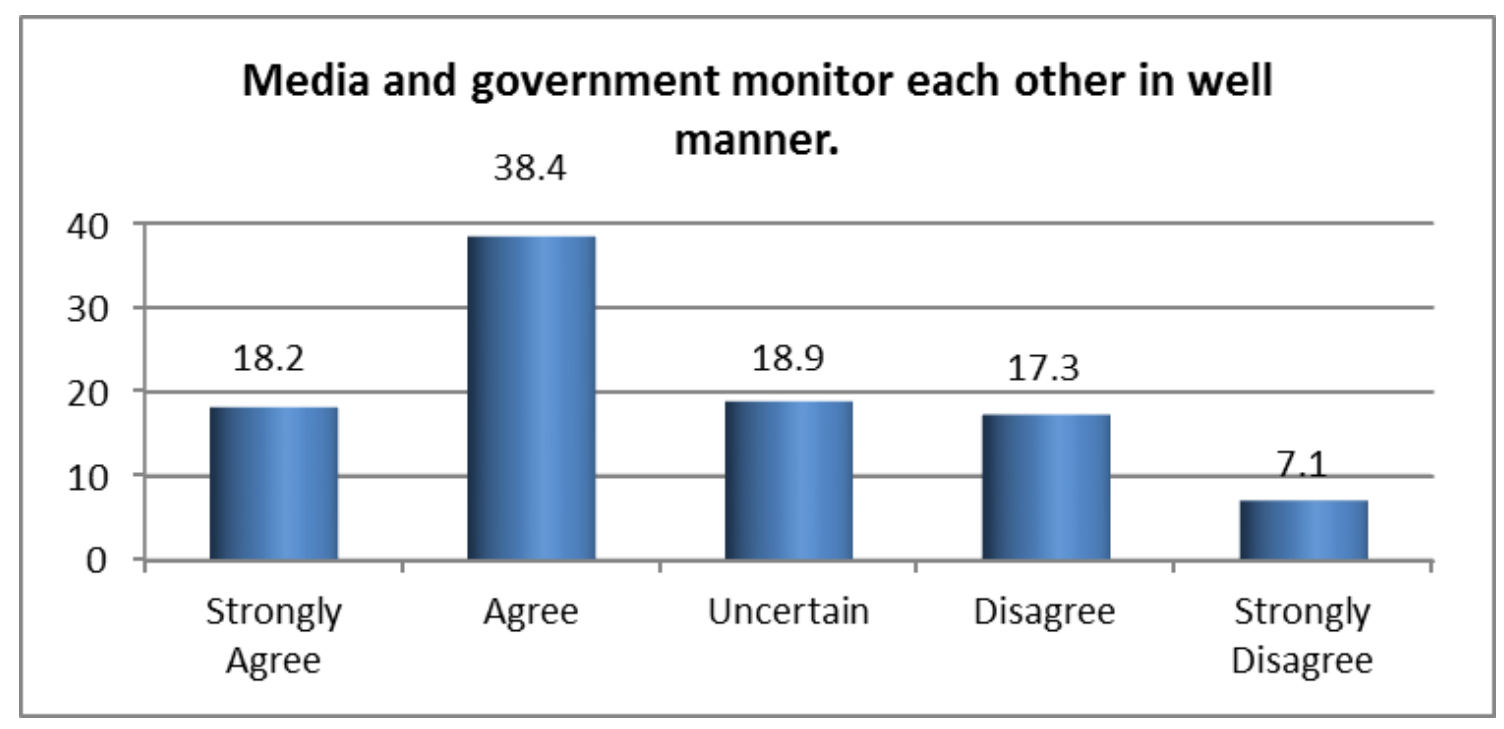

Note: The above frequency distribution graph shows the answer of statement "Media and government monitor each other in well manner." In the light of findings of question $18.2 \%$ respondents strongly agreed that media and government monitor each other in well manner, $38.4 \%$ agreed with this statement, $18.9 \%$ said that they are not sure about this statement, whereas $17.3 \%$ disagreed, and $7.1 \%$ strongly disagreed and said that media and government are same and does not monitor each other.

Figure 11. Demographic Media and government monitor each other in well manner.

\section{Discussion}

The present study conducted on to know about the relationship of media and political parties to promoting democracy. To know about the answer of the research question the researcher asked the relevant question to respondents "Media and Political Leaders both plays important role in promoting democracy?". According to the collected data, $26.4 \%$ respondents strongly agreed and said that yes media and Political Leaders both plays important role for the promotion of democracy, $38.0 \%$ respondents agreed, $14.2 \%$ respondents said that have no idea about this statement, whereas $16.2 \%$ disagreed and $5.1 \%$ respondents strong disagreed with the statement and said that media and political parties not playing their role in promoting democracy but they prefer their own interests. To know about the answer of "Media cross its limit related to its responsibilities?" the researcher asked the relevant question to public. According to the results, $27.6 \%$ respondents strongly agreed with the statement and said that media cross its limit related to its responsibilities, $22.2 \%$ respondents agreed with the statement, $26.2 \%$ respondents said that they have no idea about the answer of the respective statement, $16.9 \%$ respondents disagreed whereas $7.1 \%$ respondents strongly disagreed with the statement and said that no media not cross its limit and work fairly. To know about the answer of research question three, the researcher asked the relevant question that "Political parties pressurize media to show that contents which are in the favour of political parties". According to the collected data, 35.3\% respondents strongly agreed with the statement that political parties pressurize media to shows the contents which goes to their favour, $32.0 \%$ respondents agreed with the statement, $15.1 \%$ respondents said that they have no idea about the answer of the given statement, whereas $13.8 \%$ respondents disagreed and $3.8 \%$ respondents strongly disagreed with the statement and said that political parties do not pressurize media to show that contents which are in their favour. To know about the answer of research question, the researcher asked the relevant question to the people that "Political campaign on television convinced you to cast your vote". According to the collected data 25.1\% respondents strongly agreed that media convinced them to cast the vote, $30.7 \%$ respondents agreed about the statement, $12.9 \%$ respondents said that they are not sure and have no opinion against the respective statement, $25.1 \%$ respondents disagreed and argue that they convinced by other sources to cast the vote and $6.2 \%$ respondents strongly disagreed on the statement and said that political campaign on television has not convince them to cast the vote.

\section{Conclusions}

Present study examines "Media and Political Parties two Colours of Democracy: A Survey Study of Southern Punjab, Pakistan." In the present age, youth is playing important role in politics for making strong democratic system. If one source hides the facts, the other source highlights the facts. No one can escape from the eye of camera, because media has covered the every political event to any social issue. It is fact that voting process is the first step of democratic system. In the history of Pakistan, in general election 2013 have record voting turn-out as compare to previous all elections conducted in the country. This is positive step towards promoting democracy and in this positive step media plays vital role.

It is reality that in Pakistan, guardian decide, control and 
lead the others person of the house and all family member fallow the instruction of the guardian. But it has also seen that now this phenomenon is in changing process and every family member judge the situation according to his/her own angle. In this way youth decide own decisions.

Media is fourth pillar of the state and political parties use this media as communication tool to communicate their motive to the public. Without media political parties cannot convey their message to the people spread on large geographical area. Whereas control on media is also necessary so that it continue it's working in the laws and ethical boundaries. For each working body, monitoring is necessary so that they keep working smoothly and accurately within the limitation. So, present study concluded that media and political parties both are colour of democracy and work together for the promotion of the country.

\section{REFERENCES}

[1] Alfaro, R. M. (2006). "Citizens and media culture: Hidden behind democratic formality". Global Media and Communication, 2(3), 299-313.

[2] Christians, C., Glasser, T., McQuail, D., Nordenstreng, K. and White, R. (2009). "Normative Theories of the Media: Journalism in Democratic Societies". Urbana and Chicago: University of Illinois Press.

[3] Gina M. Garramone and Charles K. Atkin, (1986), "Mass Communication and Political Socialization: Specifying the Effects”. Public Opinion Quarterly, Vol. 50 No. 1, pp. 76-86.

[4] Loveless, Methew (2009), "The Theory of International Media Diffusion: Political Social and International Media in Transitional Democracies". Studies in Comparative International Development, 44/2: 118-36.

[5] McQuail, D. (2005). "McQuail's Mass Communication Theory". 5th ed. London: Sage.

[6] Marjut Johansson, (2008). "Presentation of the Political Self Commitment in Electoral Media Dialogue", Journal of Language and Social Psychology, Vol. 27 No. 4 (December 2008), pp. 397-408

[7] Mancini, P. (1993), "Between Trust and Suspicion: How Political Journalists solve the dilemma". European Journal of Communication 8(1), March. 33-53.

[8] Randall, Vicky (1998), "Democratization and the Media". (Frank Cass).

[9] Voltmer, Katrin \& G. Rownsley (2009), "The Media", in Christian W. Haerpfer et al. (eds), Democratization (Oxford University Press).

[10] Wheeler, M. (1997). "Politics and the Mass Media". Cambridge, Massachusetts: Blackwell. 